CAHIER DE RECHERCHE \#0911E

Département de science économique

Faculté des sciences sociales

Université d'Ottawa
WORKING PAPER \#0911E

Department of Economics

Faculty of Social Sciences

University of Ottawa

\title{
Pollution Control, Competitiveness, and Border Tax Adjustment
}

\author{
Yazid Dissou* and Terry Eyland
}

May 2009

This version September 2009

\footnotetext{
* We would like to thank without implicating, Keyvan Abedi, Selma Didic, Esuola Gbolahan, Chris Ross, Leslie Shiell, Randy Wigle, and seminar participants at the 2009 CEA Conference in Toronto and the 2009 International EcoMod Conference in Ottawa for helpful discussions and comments.

*Corresponding author: 55, Laurier Av. East, Ottawa, Ontario, Canada K1N 6N5; ydissou@uottawa.ca.
} 


\begin{abstract}
This paper explores in a general equilibrium framework the welfare and sectoral implications of an optimally designed system of border tax adjustments (BTA) on the imports of energy-intensive industries. Recently, several propositions have been made by policy makers and researchers to use BTA as a restrictive trade policy instrument to address the loss of competitiveness induced by unilateral stringent domestic pollution control policies. In this paper, we define the loss of competitiveness not as a loss of output by domestic energy-intensive producers, but instead as a loss of their market shares. We argue and we show using the Canadian economy as illustration that the most often proposed BTA, which is based on the carbon embodiment of the import good, may under-or over-achieve the objective of addressing the competitive disadvantage of domestic energy-intensive industries. In some cases, the proposed BTA may over protect the domestic energy-intensive industries by providing implicit subsidies as they might even increase their production in the presence of carbon taxes. Similarly, the proposed BTA may fail to fully restore the competitiveness of domestic producers, vis-à-vis their foreign peers. We determine the optimal BTAs on imports that fully restore the competitiveness of domestic firms following unilateral stringent pollution control policies. The 'optimal' BTAs take into consideration the general equilibrium effects of the carbon tax and of the import charges on the prices of domestic goods. In most cases, the impact their impact on import prices is higher than in the previous case. As a consequence, they entail higher distortions on resource allocation in the economy and hence higher welfare cost to households.
\end{abstract}

Key words: Border tax adjustment, competitiveness, energy-intensive industries, general equilibrium, Canada.

JEL Classification: D58, D61, H21, Q4, Q52.

\title{
Résumé
}

Cette étude examine dans un cadre d'équilibre général les impacts sectoriels et l'impact sur le bien-être d'une structure optimale des ajustements des droits de douanes (ADD) sur les importations des produits à forte intensité énergétique. Plusieurs propositions ont été récemment faites dans les milieux académiques et gouvernementaux sur l'utilisation des ADD comme instrument de politique commerciale afin de réduire la perte de compétitivité liée à l'adoption unilatérale de politiques sévères de contrôle de la pollution. Dans cette étude, nous définissons la perte de compétitivité non pas comme une perte de production des industries à forte intensité énergétiques, mais plutôt comme une perte de leurs parts de marché domestiques. Nous montrons, en nous servant de l'économie canadienne comme illustration, que l'ADD le plus souvent proposé, qui est basé sur le contenu en carbone du produit importé, peut dépasser ou peut ne pas atteindre l'objectif de réduction de la perte de compétitivité. Nous montrons que dans certains cas, l'ADD proposé peut même offrir une sur-protection aux industries nationales à forte intensité énergétique en accordant des subventions implicites à la production. Nous montrons aussi que l'ADD proposé ne parvient pas à rétablir pleinement la compétitivité des producteurs nationaux, vis-à-vis de leurs homologues étrangers. Nous déterminons la structure 'optimale' des ADD sur les importations susceptibles de restaurer pleinement la compétitivité des entreprises nationales suite à l'adoption unilatérale de sévères politiques de contrôle de la pollution. L'ADD 'optimal' prend en considération les effets d'équilibre général de la taxe sur le carbone et des taxes à l'importation sur les prix des produits domestiques. Dans la plupart des cas, l'impact de leur impact sur les prix à l'importation est plus élevé que dans le cas précédent. En conséquence, elles entraînent des distorsions plus élevés sur l'allocation des ressources dans l'économie et donc des coûts plus élevés de bien-être des ménages.

Mots clés: Ajustement des droits de douanes, compétitivité, industries à forte intensité énergétique, équilibre général, Canada

Classification JEL: D58, D61, H21, Q4, Q52. 


\section{Introduction}

This paper examines the welfare and sectoral implications of an optimally designed system of border tax adjustments (BTAs) to address the loss of competitiveness in a carbon-constrained economy. Climate change is a global problem that requires the participation of the major polluting countries, hence international cooperation is required. This cooperation is weakened by the well-known free-rider problem, whereby some individual countries are better off by taking lax actions, while other countries strive to reduce emissions through stringent actions (See Carraro and Siniscalco, 1994). The reason for this is that the use of a carbon tax or of an emission trading system, to reduce emissions, entails some costs.

Stringent environmental policies in participating countries increase the production cost and decrease the competitiveness of their energy-intensive industries, not only in international markets, but also in their domestic markets. In a world that is increasingly integrated through trade, the concern that unilateral actions may harm the competitive position of national industries has hindered the adoption of broad-based stringent environmental policies. The loss of competitiveness has been the main reason for the U.S having withdrawn from the Kyoto protocol in 2002 and also for the lack of decisive actions in other Annex 1 countries. In this context, finding remedies to the competitiveness loss would enhance the commitment of individual countries to invest lasting efforts in address in climate change.

Several avenues have been considered in the literature to alleviate the competitiveness issue brought about by the limited participation and by the use of market-based instruments to curb pollution. Recycling part of the proceeds from permit sales or carbon taxes to the sectors most affected by the GHG control policy costs is one of these options. ${ }^{1}$ An output-based allocation of free emissions allowances to GHG intensive industries is another option that has been considered to mitigate the increase in production cost. ${ }^{2}$ The drawback of these approaches is that while they can alleviate the competitiveness issue faced by GHG intensive industries, they also significantly increase the welfare cost of the abatement policy.

More recently, the use of restrictive trade policies has been suggested to address the loss of competitiveness and to force non-participating countries to join the coalition (See for example, Barrett, 2003 and Kemfert, 2004). A recurrent proposal on this front is the implementation of a border tax adjustment on the imports of energy-intensive goods from countries that do not commit to reducing their emissions. An increasing number of jurisdictions

\footnotetext{
${ }^{1}$ See Goulder (2001) and Goulder et al. (1999) for a review of these options

${ }^{2}$ See Dissou (2006) and Fischer and Fox (2007) for more details.
} 
around the world are seriously considering using carbon-motivated BTAs. The US and the EU are currently contemplating the implementation of BTAs. ${ }^{3}$

While several definitions of competitiveness loss have been proposed in the literature, in this study we view this concept, as far as the domestic market is concerned, not as a loss of output by domestic producers, but as a loss of their market shares. The reason for this is that, in the absence of technological progress that could mitigate the abatement cost, pollution control is very likely to entail a reduction in the production of energy-intensive goods. It follows that focussing on output loss may be misleading. Under these circumstances, eliminating the competitive disadvantage of domestic firms amounts to enabling them to restore their market shares prior to the carbon tax.

The ultimate objective of the BTA is to level the playing field between domestic and foreign producers, where the former face stringent environmental policies and the latter do not. In other words, the BTA is meant to restore the relative price between imports and domestic good to the level prior to the implementation of a stringent pollution control. In reality, the idea of the BTA is not a new topic (Lockwood and Whalley, 2008). It has been analysed at length after the introduction of the Value Added Tax (VAT in the European Union). Previous studies, like Meade (1974) and Grossman (1980), have shown that border tax adjustments on imports can be effective at restoring competitiveness in a situation where taxes are differentiated under the origin and destination rules.

It is worth noticing that the proposition for a carbon-motivated BTA occurred after a long series of trade liberalization episodes under the auspices of WTO whereby most trade barriers have been removed or lowered in several countries. The general consensus is that unilateral trade barriers are only a second best option when it comes to address climate change. The cost of increasing trade barriers must be taken into consideration; they affect global optimal allocation of resources, they can hurt domestic firms that rely on imported intermediate inputs and they can harm domestic consumers as well.

The typical proposal for implementing BTAs involves levying a charge on the imports of energy-intensive goods that is proportional to its carbon embodiment, i.e., to the emissions released during its production. Nevertheless, its implementation poses several challenges among which are the informational constraints on production technology as well as the legality of such

\footnotetext{
${ }^{3}$ See Godard (2007) for details.
} 
measures with WTO rules. Opinions diverge on the legality of the BTA as some authors believe that carbon-motivated BTAs do not infringe on any WTO rule ${ }^{4}$.

Besides, the determination of the appropriate level of the tax is also problematic. On the one hand, if the tax is set at a very low level, it will fail to restore competitiveness. On the other hand, if the tax is set at a very high level, it will not only act as subsidy to domestic firms, but it can also harm the economy through the increase in the deadweight loss of import tariffs. In other words, if the objective is simply to level the playing field, the border tax should be set at a level that is just sufficient to solve the problem.

Moreover, beyond the practical and legal aspects of the most often proposed approach to implementing BTA, one should note its partial equilibrium nature. The rationale for the use of a border tax based on the carbon embodiment is that producers in foreign countries should incur the same cost as if their production took place in the domestic country. Unfortunately, foreign producers do not produce their goods in the domestic economy and so they do not bear the other general equilibrium effects of the carbon tax. The assumption that the change in the relative price between domestic and import goods depends only on the direct cost of carbon tax is misleading because of its partial equilibrium perspective. Carbon taxes entail some general equilibrium effects on the output price that need to be considered as well.

Indeed, on the one hand, on the supply side, the changes in the prices of other inputs, i.e., intermediate inputs and primary factors, induced by the domestic carbon tax, can affect the price of the domestic good, and hence, its relative price to the imported good. On the other hand, on the demand side, the change in total domestic demand caused by the change in factor income and by the change in the structure of demand can affect the demand for domestic energy-intensive goods, and therefore, it can increase or decrease their prices. It ensues that the restoration of the relative price between the domestic and imported goods to its prior level could not be achieved uniquely by raising the price of the import good by the direct increase in the cost of the domestic good through the carbon tax.

Several authors have assessed the sectoral and aggregate impacts of BTAs on the imports of energy-intensive goods to restore competitiveness. These include, among several others, Babiker and Rutherford (2005), Demailly and Quirion (2006), Fischer and Fox (2008), and Ismer and Neuhoff (2004). These papers consider a partial-equilibrium type BTA and find that it can mitigate the competitiveness problem faced by internationally exposed energy-intensive industries.

4 See Goh (2004), de Cendra (2006), Ismer and Neuhoff (2007) and Fischer and Fox (2008) for interesting discussions on the legal aspects of carbon-motivated BTAs. 
The present study contributes to the above-mentioned literature by assessing, in a general equilibrium framework, the implications of an "optimal" BTA that fully restores competitiveness between domestic goods and imports in energy-intensive industries. We are not aware of any paper that addresses the issue of the optimal BTA and its welfare implications.

We consider the Canadian economy as a study case; even if the Federal government has not yet taken stringent actions to control emissions, some academics have called for the use of BTAs when stringent environmental policies will be in effect. ${ }^{5}$ We consider a carbon tax system as the policy instrument and we determine in a general equilibrium context the "optimal" or appropriate border tax adjustments on imports that will level the playing field between domestic goods and imports without providing subsidies to domestic producers. We restrict our attention to the restoration of competitiveness in the domestic market. We assess the welfare and distributional implications across industries. We compare the impacts of the optimal BTA with those of the typical partial-equilibrium view of BTA based on the carbon embodiment of the imported good.

The remainder of the paper is as follows. The next section provides a brief description of the model. In the third section, we discuss the data and describe the simulation. The fourth section discusses the results and the last concludes.

\section{Model description}

We develop a multi-sector static general equilibrium model of the Canadian economy. The model is calibrated to the data set of 2004 that captures the transactions among economic agents and the carbon dioxide emissions in the economy during that year. It provides an interesting representation of the structure of production and consumption in the economy that makes it possible to analyze the sectoral and aggregate implications of GHG mitigation policies. It captures some important dimensions in the analysis of GHG abatement policies, such as the differences in carbon intensities and various degrees of substitution possibilities across energy goods. The model features a disaggregation of the economy into 15 industries among which are four energy-producing industries (coal, oil and gas, refineries and electricity) and four energyintensive industries that do not produce energy, which are pulp and paper, cement, chemicals, and metal industry. The fifteen industries produce 19 commodities that include electricity and six fossil energy commodities, which are coal, natural gas, gasoline, diesel, liquid petroleum and other refined petroleum products.

\footnotetext{
${ }^{5}$ See Courchene and Allan (2008).
} 
Four types of economic agents are considered: households, firms, the government and the rest of the world. Physical capital and labor are mobile across industries. Canada is considered a small-open economy that considers world prices of import and export goods as given. The model focuses only on carbon dioxide $\left(\mathrm{CO}_{2}\right)$ and tracks its emissions by source (fossil fuels), and by user (industries and households).

To avoid the black-box syndrome of numerical models, we provide a cursory review of the model structure below that will help the reader grasp better the results and the transmission mechanisms involved.

\subsection{Production}

Production technology is characterized by constant returns to scale in all industries. It is represented by nested separable linear homogeneous constant elasticity of substitution (CES) production functions. Gross output in each industry is a CES function of the index of intermediate inputs and of the composite of value-added and energy. The index of valued-added and energy is a Cobb-Douglas (C-D) aggregate of labour and the index of capital and energy. The composite of capital and energy is a CES function of capital and total energy. The latter is a CES composite of electricity and the index of fossil energy, which is in turn a CES composite of coal, natural gas and refined petroleum. The index of intermediate inputs is a Leontief aggregate of other material inputs.

The representative firm in each industry considers input and output prices as given and maximizes profits in order to determine the optimal levels of input uses and output. The model assumes that $\mathrm{CO}_{2}$ emissions related to a given fossil fuel are proportional to its quantity. The carbon tax imposed on fossil fuels is based on their content of $\mathrm{CO}_{2}$ and is modelled as an excise tax. The tax increases the cost of using fuels and induces firms to pare their use through substitution effects.

Eventually, the imposition of the carbon tax increases the production cost of the firm. The magnitude of the increase in the production cost depends on several factors among which are the energy intensity of the firm and the ease of substitution among inputs. It is important to note that the increase in the production cost will not necessarily translate into an increase in the equilibrium output price. The latter is also affected by the change in demand. For example, a substantial downward shift in the demand for the product caused by a negative income effect can lead to a decline in its equilibrium price despite the increase in the production cost. The reverse is also possible, i.e., an upward shift in demand. Yet, from a general equilibrium perspective, this income effect may be important. It follows that the appraisal of the change in 
output price by the partial-equilibrium direct impact of the cost of the carbon tax may be misleading.

\subsection{Households}

The representative household derives utility from the consumption of goods. He receives income from several sources: primary factor incomes, government transfers and net transfers from the rest of the world. He pays income tax and consumption taxes on commodities. He saves a constant fraction of his disposable income and devotes the remainder for consumption.

The representative household's preferences are represented by a weakly separable utility function that is represented by a series nested CES utility functions. At the top level, the utility is represented by a CES aggregate of energy commodities and a CES aggregate of non-energy commodities. As in the production technology, the household has the possibility to substitute among various fossil fuels to produce the energy that will satisfy his needs. The optimal level for the demand of each commodity is determined through utility maximization subject to budget constraint.

\subsection{Trade and competitiveness}

In this model, we assume that domestically produced goods are imperfect substitutes to imports. We use an Armington function to capture the differentiation between goods according to their origins. Total domestic demand for each commodity (by consumers and firms) is a CES composite of the domestic good and of imports. A representative agent, who considers prices as given, determines the optimal demand for each commodity by origin through cost minimization.

The main characteristic of the optimal solution to this optimization problem is that the ratio of quantities demanded of the imported good and of the domestic good is a function of their price ratio. In particular, the ratio between the demand for the domestic good and the demand for the aggregate of imports is negatively related to their price ratio. Everything else being equal, an increase in the price of the domestic good increases the ratio between the demand for imports and the demand for the domestic good.

From this, it is easy to see how unilateral pollution control policies that increase the relative price of domestic goods vis-à-vis imports can erode the competitiveness of domestic industries. Hence, levelling the playing field between domestic and foreign producers will amount to restoring the relative price between the two goods to the level prior to the imposition of the carbon tax. If trade policy is to be used as a policy instrument to restore competitiveness, it will amount to imposing an import charge equivalent to the change in the domestic good price. Following our previous discussions, using the partial-equilibrium direct impact of the carbon tax 
on production cost to determine the appropriate charges on imports to restore competitiveness may be misleading.

Besides, on the supply side we also assume that domestic sales are imperfect substitutes to exports. We model this imperfect substitution on the supply side by using a constant elasticity of transformation (CET) function. The representative firm of each industry determines the optimal deliveries in each market by maximizing the revenue from the sales of their gross output subject to the technological constraint represented by the CET function. The ratio of exports to domestic sales depends on the relative price of the two goods; the lower the domestic price, the lower the ratio of domestic deliveries to exports. It is worth mentioning that, with the assumption of the small country, the prices of the export goods are exogenous. Changes in the volume of exports will only occur either through the changes in the prices of domestic goods (substitution effect) or through the changes in gross output that are brought about by the changes in the volume of inputs used.

\subsection{Government, equilibrium conditions and closure rules}

The government's role is very simple in this model. It derives revenue from taxes on primary factor incomes, production and consumption taxes, trade taxes and the proceeds of the carbon taxes. It distributes transfers to households and provides a public good that is produced through the purchase of commodities in the market. The provision of the public good is fixed in real terms. The government finances its expenditures with the tax revenue and its saving is endogenous.

The model determines endogenously the values of prices and quantities such that all markets clear simultaneously. The price of the domestic good must adjust to bring about equilibrium between supply and demand in that market. Equilibrium is achieved in the labour and capital markets through changes in, respectively, the wage rate and the rental rate of capital. Foreign saving is exogenous and the real exchange rate adjusts to bring about balance-ofpayments equilibrium. Finally, expenditures on investment goods are funded by total saving, and we assume that the share of each commodity in total investment spending is fixed.

\section{Data, calibration and description of the simulations}

As is usual in CGE modeling, the model is calibrated to the economic transactions and emissions of a benchmark year, 2004 in this study. We use the benchmark data along with extraneous elasticities to calibrate the other behavioural parameters so as to reproduce the benchmark 
equilibrium. ${ }^{6}$ We run three simulations with the model. The first one is the reference simulation against which we liken the results obtained in the other two.

In the first simulation, called NO-BTA, we impose a carbon tax of $\$ 40$ per tonne of $\mathrm{CO}_{2}$ on all fossil fuels used by all economic agents in the economy. We do not apply any BTA on imports. Moreover, no distinction is made on the origin of the fossil fuel. Domestically produced fossil fuels, as well as imports are subjected to the carbon tax. In the same vein, no domestic user is exempted from paying the carbon tax. In order to disentangle properly the welfare cost of the policies, we elect to return the proceeds of the carbon tax in all simulations to the government that could use the revenue to increase its balance.

In the second simulation called PE-BTA, in addition to the carbon tax, imports of energy-intensive goods must pay an additional charge, the BTA, which adds to the existing tariffs. We consider a BTA that is equivalent to the direct partial-equilibrium increase in the production cost incurred by domestic firms, which produce the same good. The BTA is unilaterally carried out as an excise tax on the imports of energy-intensive goods. The BTA depends on its carbon embodiment and on the carbon tax rate paid by domestic firms. The carbon embodiment depends on the technology used to produce the good. Incomplete information on foreign firms' technology makes it difficult to determine the carbon embodiment of imported goods. Most of the BTA propositions suggest using the carbon embodiment rates of domestic goods. The carbon embodiment of a good is the total amount (direct and indirect) of $\mathrm{CO}_{2}$ emissions that is required in the production of one unit of output. Let us denote by $t$ and $e_{i}$, respectively, the carbon tax rate $\left(\$\right.$ per tonne of $\mathrm{CO}_{2}$ ) and the carbon embodiment of the good (tonne of $\mathrm{CO}_{2}$ per unit of output). The BTA levied on the imported energy-intensive good is: t.e ${ }_{i}{ }^{7}$ We use the data on carbon embodiments of domestic energy-intensive industries produced by the Canadian Federal Statistics Office, Statistics Canada.

In a multi-country setting, the BTA should be applied on the imports of energy-intensive goods from countries with lax environmental policies. It is unnecessary to make that distinction in the context of a single-country model. The production cost of energy-intensive goods would increase in the other countries as well, should they implement stringent environmental policies. It follows that the import price of the goods from countries with stringent policies would also increase. ${ }^{8}$ Therefore, in the context of our single-country model, we elect to implement the BTA on total imports of each energy-intensive good, irrespective of origin. As mentioned before, the

\footnotetext{
${ }^{6}$ See Table 1 for the characteristics of the economy and Table 2 for the main elasticities used.

${ }^{7}$ We assume that the BTA is levied on the import price gross of the existing tariff. In other words, the government does not derive additional tariff revenue from the BTA.

${ }^{8} \mathrm{It}$ is assumed implicitly that there is no difference in the production technology of energy-intensive goods in all foreign countries.
} 
following energy-intensive goods are considered in the present model: pulp and paper; chemical products; cement and non metallic products; and metal products. The proceeds of the carbon tax and of the BTA are entirely recycled back to the government for the same reason referred to earlier in this paper.

In the third simulation called GE-BTA, in addition to the carbon tax, instead of applying an exogenously set BTA, we determine endogenously the appropriate or "optimal" BTA that will entirely restore competitiveness in each domestic energy-intensive industry. As discussed earlier, restoring competitiveness amounts to bringing the relative price between the domestic good and imports back to the level prior to the imposition of the carbon tax. In this simulation, the BTA is an ad valorem tax on imports that adds to the existing tariff. As in the previous simulation, the proceeds of the carbon tax and of the BTA are returned to the government.

In the next sub-sections, we discuss the simulation results and devote some effort to delineating the underlying transmission mechanisms. General equilibrium model results may be difficult to understand without some explanations as to their rationale. We purposely concentrate our discussion on the results in Simulation 1, and we then highlight the differences with the two other cases. In all simulations, the results are reported as percentage deviations from benchmark values unless otherwise mentioned.

\section{Simulation results}

\subsection{Simulation 1 (NO-BTA): Impact of a \$40/ton carbon tax with no border tax adjustment}

The imposition of the carbon tax on the use of all fossil fuels from all origins (domestic and foreign) increases the prices of these goods and gives incentives to their buyers to substitute away from them and reduce their use. Firms and households reduce their $\mathrm{CO}_{2}$ emissions by, respectively, 22.8 and $13.1 \%$ as shown in Table 3. The increase in the price of fossil fuels drives the production cost up and leads to a fall in output, especially in energy-intensive industries. For example, output falls in the chemical and the pulp and paper industries by, respectively, 18.5 and $6.9 \%$. The reduction in the demand for energy by energy-intensive industries leads to a fall in the demand for fossil energy products. Output declines in coal and refined petroleum product industries by, respectively, 44 and $14.6 \%$ (Table 4).

The increase in the production cost of energy-intensive industries affects both exports and imports in these industries. On the supply side, the fall in output triggered by the reduction in the use of energy has a negative impact on both exports and domestic sales. The magnitude of the fall in exports in these industries varies between $2.0 \%$ in the cement industry and $22.1 \%$ in 
the chemical industry (Table 5). The adjustment in the domestic sales of these products is also affected by the changes on the demand side, as their prices are determined endogenously, in contrast with the export goods whose prices are exogenous because of the small open economy assumption.

On the demand side, as the price of domestically produced energy-intensive goods increases, users substitute away from these goods towards imports whose prices have not changed following the implementation of the carbon tax. For example, as shown in Table 7, the price of domestic goods increases by 4.3 and $1.9 \%$ in, respectively, the chemical, and the pulp and paper industries following the implementation of the carbon tax. Domestic producers are thus put at a competitive disadvantage vis-à-vis imports in their domestic market. The final impact on the demand for imports and the demand for the domestic goods depend on the magnitude of the income effects. In the presence of a strong positive income effect, the demand for domestic good can increase despite the negative substitution effect.

Still, in the energy-intensive industries, domestic sales will be more negatively affected than imports because of the competitive disadvantage, irrespective of the magnitude of the income effect. When both demands decrease, the magnitude of the change will be larger for domestic sales. For example, as shown in Table 6, the demand for domestic goods decreases in the four energy-intensive industries. The chemical industry is hit the hardest; its domestic demand drops by $15.2 \%$ in comparison with the benchmark situation. At the same time, import demand increases in the four industries (Table 6). It is interesting to note that the increase in imports occurs despite a negative income effect, as total demand falls in all four industries. As noted earlier, total demand for each commodity is a CES aggregate of domestic demand and imports. This suggests that the positive substitution effect in the benefit of imports, which is induced by the change in the relative prices, is larger than the negative income effect driven by the fall in the demand for the composite.

Besides, the changes in relative prices brought about by the carbon tax reduce the wage rate and the rental rate of capital that fall, respectively, by 1.0 and 3.4\%. Household income falls, and their real total consumption declines as well by $1.6 \%$. As a result, households experience lower welfare. The change in household welfare measured by the equivalent variation expressed as a percentage of the benchmark GDP at market price is $-0.9 \%$. Finally, the change in the composition of final demand following the imposition of the carbon tax leads to a fall in real GDP by $0.27 \%$.

\subsection{Simulation 2 (PE BTA): \$40 carbon tax with partial-equilibrium BTA based on}




\section{carbon embodiment of imports}

In this simulation, in addition to the carbon tax, an additional charge is levied on imports of energy-intensive goods. It is important to note here that the charge is levied on the imports of non-fossil energy-intensive goods only. The use of the latter goods does not release emissions; nevertheless, their production in their country of origin entails the use of inputs, which releases emissions. ${ }^{9}$ As argued earlier, this BTA is of a partial equilibrium nature, as it does not take into consideration its direct and indirect impacts and those of the carbon tax on the price of domestic goods.

The implementation of the BTA drives the import prices of energy-intensive goods up by some magnitude, which varies between 1.8 and 6.9\% (Table 7). Consequently, imports of energy-intensive goods decrease in contrast to an increase in the previous simulation with no BTA. As argued above, the BTA based on carbon embodiment of the imported good will not necessary remove the competitive disadvantage of the domestic producers, vis-à-vis their foreign peers. The BTA may over- or, sometimes, under-correct for the competitive disadvantage of the carbon tax. As shown in Table 6, the imposition of the partial- equilibrium BTA does not completely solve the competitiveness problem in the chemical and metal industries. Domestic sales in these two industries still fall more than imports as in the previous simulation without BTA.

Figures in Table 6 suggest that the ratio of domestic sales to imports fall in both chemical and metal industries by, respectively, 12.5 and $1.7 \%$. The ratio of domestic sales to imports decreases despite the increase in the import price in the two industries by, respectively, 2.2 and $1.8 \%$ (Table 7). This result cast light on the idea that an exogenously determined levy on the imports of energy-intensive goods may not be sufficient to counteract the rise of the price of domestic goods.

In contrast, the partial-equilibrium BTA is sufficient to eliminate the competitive disadvantage in the pulp and paper industry, and in the cement industry. It has even overcorrected for the disadvantage, since the ratio of domestic sales to imports in both industries increases by, respectively, 1.2 and $24.5 \%$. The large magnitude of the change in the cement industry is explained by the size of the change in import price. Because of the high carbon embodiment in the cement product, its import price increases by $6.9 \%$, and its import volume falls by $16.6 \%$, while domestic sales increase by $7.8 \%$ in the same industry. Once more, the adjustment in the cement industry is an illustration of the idea that a partial-equilibrium

\footnotetext{
${ }^{9}$ Imports of fossil energy goods are already subjected to the carbon tax as their use entails some emissions.
} 
implementation of BTA may over protect domestic industries and introduce further distortions in resource allocation in the economy.

Note that the BTA increases production cost in all energy-intensive industries since these industries use a significant share of their own output as intermediate input. The effective rate of protection granted to these industries by the BTA decreases with the share of their own output used as intermediate input and the share of imports in total demand for the good. As indicated in Table 7, the increase in the price of the domestic good with the partial-equilibrium BTA is larger than the one in the previous simulation without BTA.

Besides, the implementation of the BTA does benefit domestic producers in the energyintensive industries, as output falls less in comparison with the previous simulation (Table 4). This result is in line with the one found in Fischer and Fox (2008) in their partial-equilibrium analysis of the impact of BTA in Canada. The startling result in the present simulation is that output increases by $7.4 \%$ in the cement industry thanks to the high BTA, while it decreased in the former simulation. Indeed, because of the large impact of the BTA on import price in the cement industry, import volume falls drastically, and domestic firms are able to increase their market share by augmenting domestic sales by $7.8 \%$. Moreover, because of the jointness in the production of domestic good and exports, the sales of cement to the rest of the world increase. Exports fall in the other industries in comparison with the simulation with no BTA, with a lower magnitude though.

As energy-intensive industries are now less affected by the carbon tax in the presence of the BTA, their emissions are less reduced; industrial emissions fall slightly less in comparison with the previous simulation, -22.5 vs. $-22.8 \%$. Overall, total emissions (including households) decrease by 20.9 vs. $21.1 \%$.

Besides, as import prices of energy-intensive goods increase, production cost increases in several industries, and the returns to labor and capital fall more in comparison with the simulation without BTA. Thus, household disposable income decreases in addition to the increase in the consumption prices of goods brought about by the carbon tax and the BTA. Their real total consumption falls more and they enjoy lower welfare in comparison to the previous simulation. The equivalent variation as a percentage of benchmark GDP is -1.04, which is $14 \%$ higher than the one obtained in the simulation without BTA.

\subsection{Simulation 3 (GE BTA): \$40 carbon tax with endogenously determined BTA}

In this simulation, we determine endogenously the "optimal" BTA that eliminates the competitive disadvantage of domestic producers in the energy-intensive industries created by the 
carbon tax. Referring to the complete elimination of the disadvantage, we seek to "level the playing field" between imports and domestic goods by bringing their relative price to the level at which it was prior to the implementation of the carbon tax. As there is an isomorphism between relative price and relative quantity ${ }^{10}$, the optimal BTA will bring the ratio of imports to domestic sales to their level prior to the carbon tax as well. It is important to note here that with the optimal BTA, in a general equilibrium framework, the demand for domestic good might fall or might increase. The most important objective is to set the BTA at a level such that in the presence of carbon taxes, the prices of imports and domestic sales change by the same magnitude.

Under these circumstances, the BTA completely addresses the competitive disadvantage of domestic producers, vis-à-vis their foreign peers. Moreover, it does not over protect domestic industries by increasing the ratio of domestic sales to imports in energy-intensive industries. The general-equilibrium nature of the BTA stems from the fact that its magnitude considers its direct and indirect impacts on the prices of domestic goods, as well as those of the carbon tax.

As expected and shown in Table 6, the general-equilibrium BTA addresses exactly the competitiveness problem in energy industries. Imports and domestic sales decrease by exactly the same magnitudes that vary between 0.8 , in the cement industry, and 6.0, in the chemical industry. The sizes of these changes are in relation with the percentage changes in the import prices induced by the BTA. The largest increase is observed in the chemical industry where the import price increases by $7.7 \%$ in reference with the benchmark situation.

The adjustment in that industry is in sharp contrast with the one observed in the previous simulation with partial-equilibrium BTA, in which the import price of chemicals increased by only $2.2 \%$, which was not sufficient to eliminate the competitiveness disadvantage. The same intuition applies for the metal industry where the optimal BTA is now $2.4 \%$ in contrast with $1.8 \%$ in the previous simulation.

In all energy-intensive industries, but the cement industry, the impact of generalequilibrium BTA on the import price is larger than that of the partial-equilibrium BTA. In the cement industry, because of its high carbon embodiment, the import charge is so high that it offers significant protection to domestic producers such that they increase their output despite the carbon tax. The optimal BTA required for restoring competitiveness in the Cement industry increases its import price by $0.6 \%$ vs. $6.9 \%$ for the BTA based on carbon embodiment.

It is worth mentioning that despite the leveling of the playing field with the optimal BTA,

10 This is due to the Armington assumption. 
output does fall in energy-intensive industries, though by a lower magnitude in comparison with the simulation with no BTA. This is another confirmation of the precedent observation concerning the beneficial impact of BTA on output in energy-intensive industries. In comparison with the previous simulation, the general-equilibrium BTA is more beneficial to the chemical and metal industries than the partial-equilibrium; output falls less in these industries in comparison with the simulation with partial-equilibrium BTA (Table 4). Still, the generalequilibrium BTA does not benefit that much the pulp and paper, and cement industries compared with the situation where the BTA is based on the carbon embodiment of the imported good.

The differences in the sectoral impacts of the general-equilibrium and partial-equilibrium BTAs are not surprising given that the partial-equilibrium BTA has over-protected the pulp and paper and the cement industries. It thus makes sense that applying a BTA that levels the playing field between imports and domestic goods in these industries will favor less output.

As with the previous simulations, exports follow the same pattern as gross output. Exports in all energy-intensive industries fall less in comparison with the simulation with no BTA. Moreover, compared with the partial-equilibrium BTA, exports decrease less in the chemical and metal industries, and fall more in the pulp and paper and cement industries.

Overall, the implementation of the optimal BTA leads to a larger decrease in the returns to labor and capital in comparison with the two previous simulations. As consumption prices increase, households decrease their real total consumption by $2.1 \%$ in reference to the benchmark; they enjoy lower welfare in comparison with the other simulations. The equivalent variation expressed in percentage of GDP is $-1.19 \%$ in this simulation vs. -0.91 in the simulation with no BTA. The optimal BTA increases the welfare cost of the carbon tax by about $30 \%$. The reason for the higher welfare cost of the general-equilibrium BTA is that the larger magnitudes of the import charges required to eliminate the competitive disadvantage introduces more distortions in resource allocation than in the previous simulations.

\section{Sensitivity analysis}

To check the robustness of our qualitative results, we perform some sensitivity analyses of our findings with respect to the values of the elasticities in production technology, household preferences, Armington, and CET function. We perform two other simulations with different values of elasticities in comparison to the base case. In the first simulation with low elasticities, we decrease all elasticities by $50 \%$. In the second simulation with high elasticities, we increase all elasticities by $50 \%$. The sensitivity analysis results presented in Table 8 confirm the robustness of 
our qualitative findings. The partial-equilibrium BTA does not necessarily fully restore competitiveness in all energy industries and it provides over-protection to some industries. The simulations also suggest that the optimal BTA introduces more distortions into resource allocation as the welfare cost is higher than without BTA and with partial-equilibrium BTA.

\section{Conclusions}

In this paper, we have analyzed the impacts of implementing a $\$ 40 /$ tonne of $\mathrm{CO}_{2}$ carbon tax along with a unilateral border tax adjustment on the imports of energy-intensive goods. We have considered two types of BTA: the partial-equilibrium BTA and the general-equilibrium BTA. The partial-equilibrium BTA is determined exogenously and depends on the carbon embodiment of the energy-intensive good. In contrast, the general-equilibrium BTA is determined endogenously to completely remove the competitive disadvantage of domestic energy-intensive industries vis-à-vis their foreign peers. We have developed a multi-sector static CGE model of the Canadian economy and have run several simulations to examine the sectoral and aggregate effects of the reform. To disentangle properly the welfare impact of the BTA, we have considered a closure rule that returns the carbon tax proceeds to the government rather than to households.

Our simulation results show that BTAs could reduce the competitive disadvantage of domestic producers in energy-intensive industries vis-à-vis their foreign peers. Their output and domestic sales fall less in comparison to the situation where no BTA is implemented. Still, leveling the playing field between domestic producers and foreign peers comes at a higher welfare cost than the one obtained in a situation with no BTA.

Our results also suggest that a partial-equilibrium BTA that is based on the carbon embodiment of the good may not be sufficient to remove completely the competitive disadvantage in some energy-intensive industries. Their domestic sales may still fall more than imports. The reason for this is that the exogenously determined BTA does not take into account the general equilibrium effects of the import charges and of the carbon taxes on the prices of domestic goods. Our results also indicate that the exogenously determined BTA may over protect some domestic producers to the point where their domestic sales rise in the presence of a carbon tax while imports fall.

In contrast, the optimal BTA is set such that the ratio of domestic sales to imports is kept to its value prior to the reform. The required percentage changes in the import prices are generally higher than the ones determined exogenously. Consequently, output falls less in energyintensive industries in comparison with a situation with no BTA and households incur a higher 
welfare loss that could be $30 \%$ higher than in a situation with no BTA.

Overall, our simulation results suggest that, while BTAs could address partially or completely the competitive disadvantage of domestic energy-intensive industries in the presence of carbon taxes, they also entail some welfare cost to households, which deserves to be considered. In both BTA schemes considered, the level of emissions abatement is slightly lower than that without additional import charges. 


\section{References}

Babiker, Mustafa H. and Thomas F. Rutherford 2005 "The Economic Effects of Border Measures in Subglobal Climate Agreements" The Energy Journal 26 (4): 99-126.

Barrett, S. (2003), Environment and Statecraft, Oxford University Press, Oxford.

Carraro, C., Siniscalco, D. (1993) "Strategies for the International Protection of the Environment" Journal of Public Economics, 52, 309-328

de Cendra, Javier (2006). "Can Emissions Trading Schemes be Coupled with Border Tax Adjustments? An Analysis vis-a-vis WTO Law." Reciel 15(2): 131-145

Courchene, T. J. and J. R. Allan (2008) "Climate Change: The Case for a Carbon Tariff/Tax." Policy Options March: 59-64.

Demailly, D., and P. Quirion (2006) "CO2 Abatement, Competitiveness and Leakage in the European Cement Industry under the EU ETS: Grandfathering versus Output-based allocation”. Climate Policy, 6, 1, pp.93-113.

Dissou, Y. (2005) "Cost-Effectiveness of the Performance Standard System to Reduce CO2 Emissions in Canada: a General Equilibrium Analysis” Resource and Energy Economics, 27, pp. 187-207

Dissou, Y. (2006) "Efficiency and Sectoral Distributional Impacts of Output-Based Emissions Allowances in Canada" Contributions to Economic Analysis \& Policy, BE Press, 5, 1. Article 26

Fischer, C., Fox, A. K. (2007) "Output-Based Allocation of Emissions Permits for Mitigating Tax and Trade Interactions" Land Economics 83(4), pp. 575-599.

Fischer, C., Fox, A. (2008) “Comparing Policies to Combat Emissions Leakage: Border Tax Adjustments versus Rebates", Resources for the future working paper.

Godard, Olivier (2007). "Unilateral European Post-Kyoto Climate Policy and Economic Adjustment at EU borders.” EDF - Ecole Polytechnique: Cahier n DDX 07-15.

Goh, Gavin (2004). "The World Trade Organization, Kyoto and Energy Tax Adjustment at the Border." Journal of World Trade 38(3): 395-423.

Goulder, L.H., Parry, I.W.H., Williams III, R.C., Burtraw, D. (1999) “The Cost-

Effectiveness of Alternative Instruments for Environmental Protection in a Second-best Setting” Journal of Public Economics Volume 72, Issue 3, pp. 329-360.

Goulder, L. H. (2001) "Confronting the Adverse Industry Impacts of CO2 Abatement Policies: What Does It Cost?" in M. A. Toman (ed.) Climate Change, Economics and Policy: an RFF Anthology, 125133, Resources for the Future, Washington D.C.

Grossman, G. M. (1980). “Border Tax adjustments: Do they Distort Trade?”, Journal of International Economics, 10, 1, pp. 117-128

Ismer, Roland and Karsten Neuhoff (2007). "Border Tax Adjustment: a Feasible Way to Support Stringent Emission Trading." European Journal of Law and Economics 24: 137-164.

Kemfert,C. (2004). "Climate Coalitions and International Trade: Assessment of Cooperation Incentives by Issue Linkage", Energy Policy, 32, 4, An Economic Analysis of Climate Policy: Essays in Honour of Andries Nentjes, March 2004, 455-465

Lockwood, B. and J. Whalley (2008) Carbon Motivated Border Tax Adjustments: Old Wine in Green Bottles? NBER Working Paper 14025.

Meade, J. E. (1974). “A Note on Border-Tax Adjustments”, Journal of Political Economy, 82, 5, pp. 10131015. 
Table 1: Some characteristics of the economy is the benchmark situation

\begin{tabular}{|c|c|c|c|c|c|c|}
\hline Industries & $\begin{array}{r}\text { Shares in } \\
\text { GDP at } \\
\text { factor cost }\end{array}$ & $\begin{array}{r}\text { Shares in } \\
\text { total } \\
\text { imports }\end{array}$ & $\begin{array}{r}\text { Shares in } \\
\text { total } \\
\text { exports }\end{array}$ & $\begin{array}{r}\text { Ratio of } \\
\text { imports to } \\
\text { domestic } \\
\text { sale }\end{array}$ & $\begin{array}{r}\text { Shares in } \\
\text { industrial } \\
\mathrm{CO}_{2} \\
\text { emissions }\end{array}$ & $\begin{array}{r}\text { Carbon } \\
\text { embodiment } \\
\text { (tonne of } \mathrm{CO}_{2} \\
\text { per } \$ \text { million } \\
\text { of outnut) }\end{array}$ \\
\hline Agriculture & $2.1 \%$ & $1.8 \%$ & $2.0 \%$ & 0.16 & $3.0 \%$ & 1.7 \\
\hline Oil and gas & $6.3 \%$ & $4.7 \%$ & $10.8 \%$ & 0.42 & $16.2 \%$ & 1.2 \\
\hline Coal & $0.1 \%$ & $0.3 \%$ & $0.2 \%$ & 2.15 & $0.2 \%$ & 1.3 \\
\hline Other mining & $1.0 \%$ & $0.8 \%$ & $1.9 \%$ & 0.38 & $1.3 \%$ & 0.9 \\
\hline Power generation & $2.2 \%$ & $0.3 \%$ & $0.4 \%$ & 0.04 & $24.8 \%$ & 4.8 \\
\hline Gas pipelines & $0.7 \%$ & $0.1 \%$ & $0.7 \%$ & 0.05 & $1.9 \%$ & 0.1 \\
\hline $\begin{array}{l}\text { Pulp and paper* } \\
\text { Paper manufacturing \& }\end{array}$ & $0.9 \%$ & $1.6 \%$ & $4.2 \%$ & 0.49 & $2.1 \%$ & 2.3 \\
\hline printing & $0.5 \%$ & $0.9 \%$ & $0.5 \%$ & 0.41 & $0.1 \%$ & 0.5 \\
\hline $\begin{array}{l}\text { Other manufacturing } \\
\text { Refined petroleum }\end{array}$ & $8.2 \%$ & $43.9 \%$ & $38.5 \%$ & 1.50 & $2.2 \%$ & 0.8 \\
\hline products & $0.4 \%$ & $1.3 \%$ & $2.2 \%$ & 1.28 & $5.8 \%$ & 11.5 \\
\hline $\begin{array}{l}\text { Chemical \& rubber } \\
\text { products* } \\
\text { Cement \& non metallic }\end{array}$ & $2.2 \%$ & $11.0 \%$ & $7.9 \%$ & 1.20 & $3.8 \%$ & 1.7 \\
\hline products $^{*}$ & $0.5 \%$ & $1.0 \%$ & $0.6 \%$ & 0.43 & $3.5 \%$ & 4.0 \\
\hline Metal industry* & $3.4 \%$ & $16.8 \%$ & $11.9 \%$ & 1.43 & $5.6 \%$ & 1.3 \\
\hline Transport & $3.1 \%$ & $1.9 \%$ & $4.5 \%$ & 0.15 & $10.1 \%$ & 2.3 \\
\hline Services & $68.4 \%$ & $13.5 \%$ & $13.8 \%$ & 0.05 & $19.2 \%$ & 0.4 \\
\hline
\end{tabular}

* Energy-intensive industry

Source: Statistcis Canad and Owner calculations

Table 2: Ranges of the valuses of the elasticities of substitution in the base case

\begin{tabular}{lrr}
\hline & Min & Max \\
\hline Index of value added energy and index of intermediate inputs & 0.2 & 0.7 \\
Index of capital energy and labour & 0.4 & 0.7 \\
Capital and Index of energy & 0.3 & 0.6 \\
Electricity and Index of fossil fuels & 0.45 & 0.9 \\
Among fossil fuels & 0.5 & 0.9 \\
Among non-motive fossil fuels & 0.5 & 0.9 \\
Index of material inputs and index of motive fossil fuels & 0.3 & 0.6 \\
Among motive fossil fuels & 0.5 & 0.9 \\
Household & 0.4 & 1.7 \\
Armington function & 2 & 4.5 \\
CET function & 2 & 4.5 \\
\hline
\end{tabular}


Table 3: Aggregate impact of a $\$ 40$ carbon tax with and without BTA

Percentage deviation from benchmark

\begin{tabular}{lrrr}
\hline & No BTA & $\begin{array}{r}\text { BTA based on "Optimal" BTA } \\
\text { carbon content }\end{array}$ \\
\hline GDP at market price & -0.27 & -0.28 & -0.30 \\
Total real imports & -1.04 & -2.19 & -3.10 \\
Total real exports & -0.93 & -1.95 & -2.76 \\
Real exchange rate & 0.40 & 0.39 & 0.43 \\
Rental rate of capital & -3.42 & -3.63 & -3.84 \\
Nominal wage rate & -1.04 & -1.32 & -1.65 \\
Household disposable income & -1.19 & -1.41 & -1.67 \\
Household real consumption & -1.58 & -1.82 & -2.07 \\
Equivalent variation as \% of GDP & -0.91 & -1.04 & -1.19 \\
Industrial emissions & -22.76 & -22.51 & -22.17 \\
Household emissions & -13.14 & -13.28 & -13.45 \\
Total emissions & -21.10 & -20.91 & -20.66 \\
\hline
\end{tabular}


Table 4: Industry impact of a $\$ \mathbf{4 0}$ carbon tax with and without BTA

Percentage deviation from benchmark

\begin{tabular}{|c|c|c|c|c|c|c|c|c|c|c|c|c|}
\hline & \multicolumn{3}{|c|}{ Output } & \multicolumn{3}{|c|}{ Total energy demand } & \multicolumn{3}{|c|}{ Output price } & \multicolumn{3}{|c|}{ Total energy price } \\
\hline & NO-BTA & $\begin{array}{r}\text { BTA based } \\
\text { on carbon } \\
\text { content }\end{array}$ & $\begin{array}{r}\text { "Optimal" } \\
\text { BTA }\end{array}$ & No BTA & $\begin{array}{r}\text { BTA based } \\
\text { on carbon } \\
\text { content }\end{array}$ & $\begin{array}{r}\text { "Optimal" } \\
\text { BTA }\end{array}$ & No BTA & $\begin{array}{r}\text { BTA based } \\
\text { on carbon } \\
\text { content }\end{array}$ & $\begin{array}{r}\text { "Optimal" } \\
\text { BTA }\end{array}$ & No BTA & $\begin{array}{r}\text { BTA based } \\
\text { on carbon } \\
\text { content }\end{array}$ & $\begin{array}{r}\text { "Optimal" } \\
\text { BTA }\end{array}$ \\
\hline Agriculture & 3.5 & 1.3 & -0.8 & -1.3 & -3.2 & -5.0 & -0.1 & 0.0 & 0.1 & 14.1 & 13.9 & 13.7 \\
\hline Oil and gas & -5.8 & -5.0 & -3.9 & -10.4 & -9.6 & -8.6 & -1.7 & -1.8 & -2.0 & 16.9 & 16.7 & 16.5 \\
\hline Coal & -44.0 & -43.4 & -43.1 & -47.2 & -46.5 & -46.3 & 0.0 & -0.1 & -0.2 & 15.4 & 15.3 & 15.1 \\
\hline Other mining & -3.4 & -2.1 & -2.1 & -9.2 & -8.0 & -7.9 & 0.0 & -0.1 & -0.2 & 16.4 & 16.3 & 16.0 \\
\hline Power generation & -5.1 & -5.0 & -5.0 & -27.2 & -27.1 & -27.1 & 6.2 & 6.0 & 5.8 & 97.5 & 97.3 & 97.1 \\
\hline Gas pipelines & -11.2 & -10.8 & -10.5 & -16.9 & -16.5 & -16.2 & -1.3 & -1.5 & -1.7 & 16.8 & 16.6 & 16.4 \\
\hline Pulp and paper* & -6.9 & -4.9 & -6.9 & -11.9 & -9.9 & -11.7 & 0.8 & 1.1 & 1.4 & 12.1 & 11.9 & 11.7 \\
\hline Paper manufacturing \& printing & 0.3 & -0.5 & -1.0 & -5.1 & -5.8 & -6.2 & -0.4 & -0.1 & 0.1 & 15.4 & 15.3 & 15.1 \\
\hline Other manufacturing & 6.3 & 3.2 & 0.8 & 0.7 & -2.1 & -4.3 & -0.5 & -0.3 & -0.1 & 14.5 & 14.4 & 14.2 \\
\hline Refined petroleum products & -14.6 & -14.6 & -14.6 & -23.0 & -22.9 & -22.9 & 1.1 & 1.0 & 1.0 & 24.6 & 24.5 & 24.5 \\
\hline Chemical \& rubber products* & -18.5 & -16.9 & -12.3 & -25.5 & -23.8 & -19.1 & 2.2 & 2.8 & 4.1 & 22.2 & 22.0 & 21.9 \\
\hline Cement \& non metallic products ${ }^{\star}$ & -1.2 & 7.4 & -1.0 & -7.9 & 0.3 & -7.6 & 0.4 & 0.8 & 0.4 & 17.3 & 17.1 & 16.9 \\
\hline Metal industry* & -5.2 & -4.1 & -3.7 & -16.5 & -15.5 & -15.1 & 0.6 & 1.1 & 1.1 & 33.2 & 33.1 & 32.8 \\
\hline Transport & -4.1 & -4.0 & -4.0 & -12.6 & -12.6 & -12.8 & 1.4 & 1.3 & 1.1 & 16.7 & 16.6 & 16.4 \\
\hline Services & 0.3 & 0.4 & 0.4 & -8.8 & -8.8 & -8.8 & -0.7 & -0.8 & -1.0 & 16.2 & 16.0 & 15.8 \\
\hline
\end{tabular}

* Energy-intensive industry 
Table 5: Impact on commodity supply of a $\$ 40$ carbon tax with and without BTA

Percentage deviation from benchmark

\begin{tabular}{|c|c|c|c|c|c|c|c|c|c|}
\hline & \multicolumn{3}{|c|}{ Supply } & \multicolumn{3}{|c|}{ Exports } & \multicolumn{3}{|c|}{ Domestic sales } \\
\hline & No BTA & $\begin{array}{r}\text { BTA based on } \\
\text { carbon } \\
\text { content }\end{array}$ & " BTA & No BTA & $\begin{array}{r}\text { BTA based } \\
\text { on carbon } \\
\text { content }\end{array}$ & $\begin{array}{r}\text { "Optimal" } \\
\text { BTA }\end{array}$ & No BTA & $\begin{array}{r}\text { BTA based } \\
\text { on carbon } \\
\text { content }\end{array}$ & $\begin{array}{r}\text { "Optimal" } \\
\text { BTA }\end{array}$ \\
\hline Agriculture & 3.5 & 1.3 & -0.8 & 3.7 & 1.3 & -1.0 & 3.4 & 1.2 & -0.8 \\
\hline Coal & -44.0 & -43.4 & -43.1 & -44.0 & -43.2 & -42.9 & -44.1 & -43.6 & -43.4 \\
\hline Other mining & -3.4 & -2.1 & -2.1 & -3.3 & -1.9 & -1.7 & -3.5 & -2.3 & -2.5 \\
\hline Power generation & -5.1 & -5.0 & -5.0 & -15.9 & -15.5 & -15.2 & -4.5 & -4.3 & -4.4 \\
\hline Gas pipelines & -11.2 & -10.8 & -10.5 & -8.9 & -8.2 & -7.5 & -12.2 & -12.0 & -11.8 \\
\hline Pulp and paper* & -6.9 & -4.9 & -6.9 & -8.3 & -7.0 & -9.4 & -4.9 & -2.0 & -3.5 \\
\hline $\begin{array}{l}\text { Paper manufacturing \& } \\
\text { printing }\end{array}$ & 0.3 & -0.5 & -1.0 & 1.0 & -0.4 & -1.2 & 0.2 & -0.5 & -0.9 \\
\hline Other manufacturing & 6.3 & 3.2 & 0.8 & 7.3 & 3.8 & 1.0 & 4.8 & 2.4 & 0.4 \\
\hline $\begin{array}{l}\text { Chemical \& rubber } \\
\text { products* }\end{array}$ & -18.5 & -16.9 & -12.3 & -22.1 & -21.4 & -19.0 & -15.2 & -12.8 & -6.0 \\
\hline $\begin{array}{l}\text { Cement \& non metallic } \\
\text { products* }\end{array}$ & -1.2 & 7.4 & -1.0 & -2.0 & 5.8 & -1.9 & -1.0 & 7.8 & -0.8 \\
\hline Metal industry* & -5.2 & -4.1 & -3.7 & -6.3 & -6.1 & -5.8 & -3.8 & -1.9 & -1.3 \\
\hline Transport & -4.1 & -4.0 & -4.0 & -6.7 & -6.5 & -6.2 & -3.0 & -3.0 & -3.2 \\
\hline Services & 0.3 & 0.4 & 0.4 & 1.8 & 2.0 & 2.4 & 0.3 & 0.3 & 0.3 \\
\hline Crude oil & -5.0 & -4.3 & -3.2 & -2.7 & -1.7 & -0.3 & -7.8 & -7.3 & -6.6 \\
\hline Natural gas & -6.5 & -5.8 & -4.7 & -2.2 & -1.2 & 0.2 & -10.7 & -10.3 & -9.5 \\
\hline Gasoline & -12.9 & -12.9 & -13.0 & -17.0 & -16.8 & -16.7 & -12.2 & -12.2 & -12.4 \\
\hline Diesel & -12.8 & -12.8 & -12.8 & -17.0 & -16.9 & -16.8 & -11.7 & -11.7 & -11.7 \\
\hline Liquid petroleum & -19.0 & -18.8 & -18.4 & -14.9 & -14.9 & -14.9 & -21.9 & -21.6 & -21.0 \\
\hline $\begin{array}{l}\text { Other refined petroleum } \\
\text { products }\end{array}$ & -21.3 & -21.2 & -20.9 & -14.1 & -14.0 & -14.0 & -23.9 & -23.8 & -23.5 \\
\hline
\end{tabular}

* Energy-intensive industry 
Table 6: Impact on commodity demand of a \$40 carbon tax with and without BTA

Percentage deviation from benchmark

\begin{tabular}{|c|c|c|c|c|c|c|c|c|c|c|c|c|c|c|c|}
\hline & \multicolumn{3}{|c|}{ Total demand } & \multicolumn{3}{|c|}{ Domestic sales } & \multicolumn{3}{|c|}{ Imports } & \multicolumn{3}{|c|}{ Ratio of domestic sales to imports } & \multicolumn{3}{|c|}{ Consumption } \\
\hline & No BTA & $\begin{array}{r}\text { BTA based } \\
\text { on carbon } \\
\text { content } \\
\end{array}$ & $\begin{array}{r}\text { "Optimal" } \\
\text { BTA }\end{array}$ & No BTA & $\begin{array}{r}\text { BTA based } \\
\text { on carbon } \\
\text { content } \\
\end{array}$ & $\begin{array}{r}\text { "Optimal" } \\
\text { BTA }\end{array}$ & No BTA & $\begin{array}{r}\text { BTA based } \\
\text { on carbon } \\
\text { content } \\
\end{array}$ & $\begin{array}{r}\text { "Optimal" } \\
\text { BTA }\end{array}$ & No BTA & $\begin{array}{r}\text { BTA based } \\
\text { on carbon } \\
\text { content } \\
\end{array}$ & $\begin{array}{r}\text { "Optimal" } \\
\text { BTA }\end{array}$ & No BTA & $\begin{array}{r}\text { BTA based } \\
\text { on carbon } \\
\text { content } \\
\end{array}$ & $\begin{array}{r}\text { "Optimal" } \\
\text { BTA }\end{array}$ \\
\hline Agriculture & 3.4 & 1.2 & -0.7 & 3.4 & 1.2 & -0.8 & 2.8 & 1.0 & -0.2 & 0.6 & 0.2 & -0.6 & -1.7 & -2.0 & -2.5 \\
\hline Coal & -45.3 & -45.0 & -45.1 & -44.1 & -43.6 & -43.4 & -44.4 & -44.3 & -44.4 & 0.3 & 0.7 & 1.1 & -75.0 & -75.1 & -75.1 \\
\hline Other mining & -3.7 & -2.6 & -3.1 & -3.5 & -2.3 & -2.5 & -4.0 & -3.3 & -4.3 & 0.4 & 1.0 & 1.8 & -1.8 & -1.9 & -1.9 \\
\hline Power generation & -3.4 & -3.2 & -3.3 & -4.5 & -4.3 & -4.4 & 27.2 & 26.5 & 25.3 & -31.7 & -30.8 & -29.6 & -3.0 & -3.1 & -3.2 \\
\hline Gas pipelines & -12.5 & -12.3 & -12.2 & -12.2 & -12.0 & -11.8 & -19.3 & -19.9 & -20.8 & 7.1 & 8.0 & 9.0 & -15.5 & -15.5 & -15.6 \\
\hline Pulp and paper* & -2.2 & -2.4 & -3.5 & -4.9 & -2.0 & -3.5 & 3.4 & -3.2 & -3.5 & -8.2 & 1.2 & 0.0 & -3.7 & -6.0 & -6.8 \\
\hline $\begin{array}{l}\text { Paper manufacturing } \\
\text { \& printing }\end{array}$ & -0.4 & -0.6 & -0.8 & 0.2 & -0.5 & -0.9 & -1.8 & -0.8 & -0.3 & 1.9 & 0.3 & -0.6 & -1.5 & -2.0 & -2.5 \\
\hline Other manufacturing & 1.6 & 0.6 & -0.3 & 4.8 & 2.4 & 0.4 & -0.5 & -0.7 & -0.9 & 5.3 & 3.1 & 1.3 & -1.2 & -1.7 & -2.2 \\
\hline $\begin{array}{l}\text { Chemical \& rubber } \\
\text { products* }\end{array}$ & -5.7 & -6.1 & -6.1 & -15.2 & -12.8 & -6.0 & 2.5 & -0.3 & -6.0 & -17.7 & -12.5 & 0.0 & -4.6 & -7.1 & -12.7 \\
\hline $\begin{array}{l}\text { Cement \& non } \\
\text { metallic products* }\end{array}$ & -0.3 & 0.3 & -0.8 & -1.0 & 7.8 & -0.8 & 1.4 & -16.6 & -0.8 & -2.4 & 24.5 & 0.0 & -2.4 & -5.8 & -3.2 \\
\hline Metal industry* & -0.3 & -0.9 & -1.3 & -3.8 & -1.9 & -1.3 & 2.1 & -0.2 & -1.3 & -5.9 & -1.7 & 0.0 & -2.7 & -5.0 & -5.7 \\
\hline Transport & -1.8 & -2.0 & -2.2 & -3.0 & -3.0 & -3.2 & 5.9 & 5.1 & 3.9 & -8.9 & -8.1 & -7.1 & -4.4 & -4.3 & -4.3 \\
\hline Services & 0.1 & 0.1 & 0.1 & 0.3 & 0.3 & 0.3 & -3.2 & -3.6 & -4.2 & 3.4 & 3.9 & 4.5 & -0.8 & -0.9 & -0.9 \\
\hline Crude oil & -12.5 & -12.4 & -12.2 & -7.8 & -7.3 & -6.6 & -18.3 & -18.7 & -19.2 & 10.5 & 11.4 & 12.6 & 0.0 & 0.0 & 0.0 \\
\hline Natural gas & -12.5 & -12.1 & -11.5 & -10.7 & -10.3 & -9.5 & -27.3 & -27.7 & -28.1 & 16.5 & 17.4 & 18.6 & -15.5 & -15.5 & -15.6 \\
\hline Gasoline & -11.4 & -11.6 & -11.7 & -12.2 & -12.2 & -12.4 & -0.4 & -1.0 & -1.7 & -11.8 & -11.2 & -10.6 & -10.6 & -10.8 & -11.0 \\
\hline Diesel & -10.6 & -10.7 & -10.8 & -11.7 & -11.7 & -11.7 & 1.6 & 1.3 & 0.7 & -13.3 & -12.9 & -12.4 & -7.0 & -7.2 & -7.5 \\
\hline Liquid petroleum & -23.1 & -22.8 & -22.0 & -21.9 & -21.6 & -21.0 & -35.6 & -34.9 & -33.1 & 13.6 & 13.3 & 12.1 & -29.3 & -29.5 & -30.0 \\
\hline $\begin{array}{l}\text { Oner revined } \\
\text { petroleum products }\end{array}$ & -28.7 & -28.6 & -28.2 & -23.9 & -23.8 & -23.5 & -41.9 & -41.8 & -41.1 & 18.1 & 18.1 & 17.6 & -35.5 & -35.7 & -36.0 \\
\hline
\end{tabular}


Table 7: Impact on commodity prices of a $\$ \mathbf{4 0}$ carbon tax with and without BTA

Percentage deviation from benchmark

\begin{tabular}{|c|c|c|c|c|c|c|c|c|c|c|c|c|}
\hline & \multicolumn{3}{|c|}{ Domestic good price } & \multicolumn{3}{|c|}{ Import good price } & \multicolumn{3}{|c|}{ Ratio of domestic good to import prices } & \multicolumn{3}{|c|}{ Consumption good price } \\
\hline & No BTA & $\begin{array}{r}\text { BTA based } \\
\text { on carbon } \\
\text { content }\end{array}$ & $\begin{array}{r}\text { "Optimal" } \\
\text { BTA }\end{array}$ & No BTA & $\begin{array}{r}\text { BTA based } \\
\text { on carbon } \\
\text { content }\end{array}$ & $\begin{array}{r}\text { "Optimal" } \\
\text { BTA }\end{array}$ & No BTA & $\begin{array}{r}\text { BTA based } \\
\text { on carbon } \\
\text { content }\end{array}$ & "Optimal" BTA & "No BTA & $\begin{array}{r}\text { BTA based } \\
\text { on carbon } \\
\text { content }\end{array}$ & $\begin{array}{r}\text { "Optimal" } \\
\text { BTA }\end{array}$ \\
\hline Agriculture & -0.1 & 0.0 & 0.1 & 0.0 & 0.0 & 0.0 & -0.1 & 0.0 & 0.1 & -0.1 & 0.0 & 0.1 \\
\hline Coal & -0.1 & -0.3 & -0.4 & 0.0 & 0.0 & 0.0 & -0.1 & -0.3 & -0.4 & 221.4 & 221.4 & 221.3 \\
\hline Other mining & -0.1 & -0.2 & -0.4 & 0.0 & 0.0 & 0.0 & -0.1 & -0.2 & -0.4 & -0.1 & -0.2 & -0.3 \\
\hline Power generation & 6.6 & 6.4 & 6.2 & 0.0 & 0.0 & 0.0 & 6.6 & 6.4 & 6.2 & 6.3 & 6.1 & 5.9 \\
\hline Gas pipelines & -1.8 & -2.1 & -2.4 & 0.0 & 0.0 & 0.0 & -1.8 & -2.1 & -2.4 & -1.8 & -2.0 & -2.3 \\
\hline $\begin{array}{l}\text { Pulp and paper* } \\
\text { Paper manufacturing \& }\end{array}$ & 1.9 & 2.7 & 3.2 & 0.0 & 2.9 & 3.2 & 1.9 & -0.3 & 0.0 & 1.2 & 2.7 & 3.2 \\
\hline printing & -0.4 & -0.1 & 0.1 & 0.0 & 0.0 & 0.0 & -0.4 & -0.1 & 0.1 & -0.3 & 0.0 & 0.1 \\
\hline $\begin{array}{l}\text { Other manufacturing } \\
\text { Chemical \& rubber }\end{array}$ & -1.2 & -0.7 & -0.3 & 0.0 & 0.0 & 0.0 & -1.2 & -0.7 & -0.3 & -0.5 & -0.3 & -0.1 \\
\hline $\begin{array}{l}\text { products }^{\star} \\
\text { Cement \& non metallic }\end{array}$ & 4.3 & 5.3 & 7.7 & 0.0 & 2.2 & 7.7 & 4.3 & 3.1 & 0.0 & 1.9 & 3.6 & 7.7 \\
\hline products* & 0.5 & 1.0 & 0.6 & 0.0 & 6.9 & 0.6 & 0.5 & -5.9 & 0.0 & 0.4 & 2.6 & 0.6 \\
\hline Metal industry* & 1.3 & 2.2 & 2.4 & 0.0 & 1.8 & 2.4 & 1.3 & 0.4 & 0.0 & 0.5 & 2.0 & 2.4 \\
\hline Transport & 2.0 & 1.8 & 1.6 & 0.0 & 0.0 & 0.0 & 2.0 & 1.8 & 1.6 & 1.7 & 1.6 & 1.4 \\
\hline Services & -0.8 & -0.9 & -1.0 & 0.0 & 0.0 & 0.0 & -0.8 & -0.9 & -1.0 & -0.7 & -0.8 & -1.0 \\
\hline Crude oil & -2.7 & -2.9 & -3.2 & 0.0 & 0.0 & 0.0 & -2.7 & -2.9 & -3.2 & 0.0 & 0.0 & 0.0 \\
\hline Natural gas & -4.5 & -4.7 & -5.0 & 0.0 & 0.0 & 0.0 & -4.5 & -4.7 & -5.0 & 23.6 & 23.3 & 23.1 \\
\hline Gasoline & 2.8 & 2.7 & 2.6 & 0.0 & 0.0 & 0.0 & 2.8 & 2.7 & 2.6 & 25.8 & 25.7 & 25.6 \\
\hline Diesel & 3.2 & 3.1 & 3.0 & 0.0 & 0.0 & 0.0 & 3.2 & 3.1 & 3.0 & 21.0 & 20.9 & 20.8 \\
\hline $\begin{array}{l}\text { Liquid petroleum } \\
\text { Other refined petroleum }\end{array}$ & -4.2 & -4.1 & -3.6 & 0.0 & 0.0 & 0.0 & -4.2 & -4.1 & -3.6 & 32.1 & 32.2 & 32.6 \\
\hline products & -5.8 & -5.8 & -5.7 & 0.0 & 0.0 & 0.0 & -5.8 & -5.8 & -5.7 & 44.8 & 44.9 & 45.0 \\
\hline
\end{tabular}

* Energy-intensive industry 
Table 8: Sensitivity analysis of the impact of a $\$ 40$ carbon tax with and without BTA Low and high values of elasticities

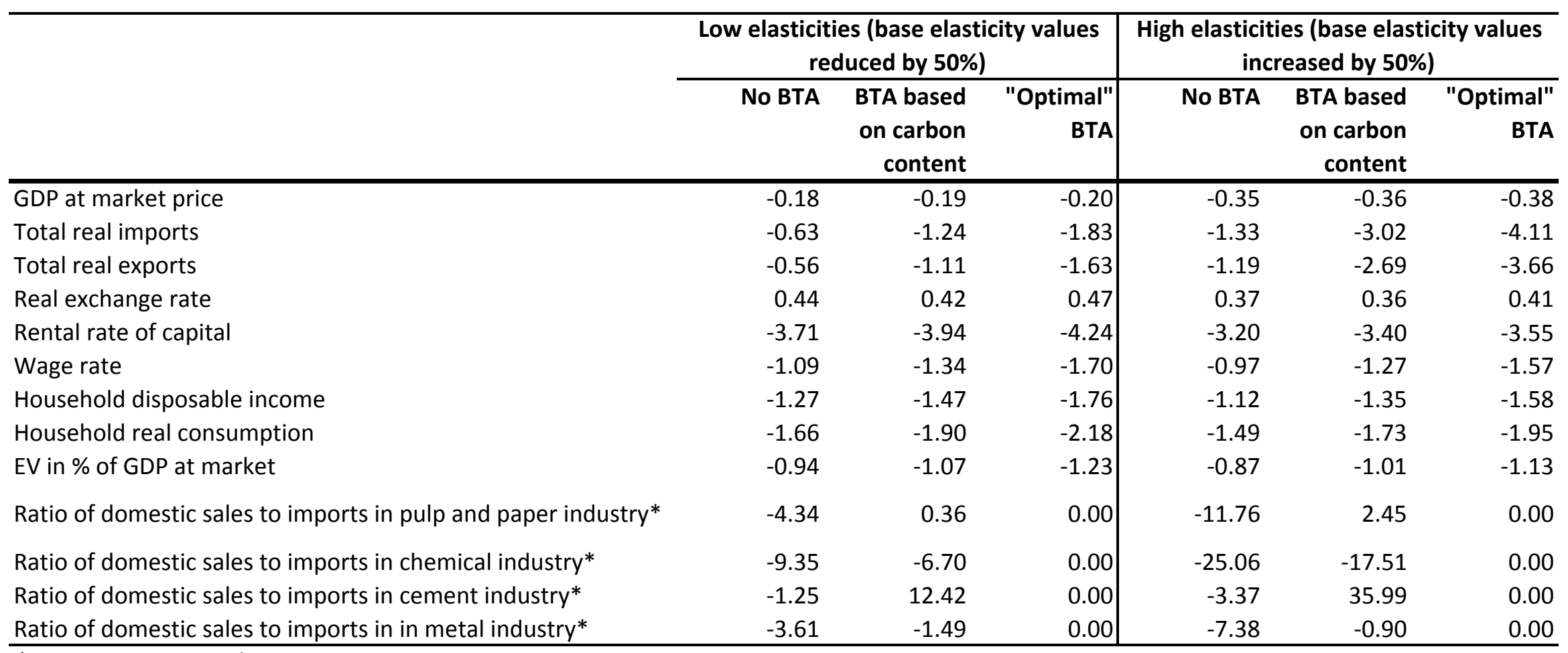

\footnotetext{
* Energy-intensive industry
} 